\title{
TESZTBERENDEZÉS TÁVVEZETÉKRÔLL LESZAKADÓ JÉG KELTETTE LENGÉSEK MODELLEZÉSÉRE
}

\author{
Lajber Kristóf ${ }^{a^{*}}$, Borbély Tibor ${ }^{b}$, Kollár László $^{c}$, Szilvágyi Milán $^{d}$ \\ a ELTE Informatikai Kar, Savaria Müszaki Intézet, PhD hallgató \\ ${ }^{b}$ ELTE Informatikai Kar, Savaria Múszaki Intézet, egyetemi docens \\ ${ }^{c}$ ELTE Informatikai Kar, Savaria Múszaki Intézet, egyetemi tanár \\ ${ }^{d}$ ELTE Informatikai Kar, Savaria Múszaki Intézet, Gépészmérnöki BSc, 4. évf.
}

\begin{abstract}
ABSZTRAKT
A cikk bemutatja egy elektromos távvezetékrôl történó jégleválás modellezésére készült rendszer felépítését és múködésének tesztelését. A valóságoshoz képest kicsinyített méretû vezetékmodell vezetékeinek befogásánál erômérô cellák vannak beépítve a vezetéklengések közben fellépô erôk mérésére. A vizsgálatok során a vezetékrôl leszakadó jeget súlyok modellezik, melyek elektromágnessel lettek rögzítve a vezetékre. Az elektromágnesek vezérlésére egy egyedi, mikrovezérlő alapú vezérlőrendszer készült el. Ismertetjük a megvalósított vezérlőrendszer felépítését és a mérôrendszerrel való együttmúködés képességének vizsgálatát.
\end{abstract}

Kulcsszavak: vezérló, távvezeték, lengések, jegesedés

\section{Bevezetés}

A villamos távvezetékeket különböző természeti jelenségek következményeként olyan hatások érik, amelyek lengéseket okoznak. A lengések közben ható nagy erôk rövid idő alatt károkat okozhatnak a távvezeték összetevóiben, de kisebb lengéseknek is lehetnek káros következményei, ha azok gyakran ismétlődnek, mert kifáradáshoz vezetnek. A nagyfeszültségú vezetékek ilyen lengéseit a lengés amplitúdója és frekvenciája alapján három fố csoportba soroljuk [1, 2]:

- A nagy amplitúdójú (összemérhető a belógással), kis frekvenciájú (0,1-1 Hz) úgynevezett „galoppozó" lengéseket a szél okozza. Ehhez hasonló, de időben csillapodó lengések alakulhatnak ki a vezetéken kialakult jég, vagy hó leválásakor. Ezek a lengések jelentôs terhelésnövekedést jelentenek a befogásoknál.

- A közepes amplitúdójú és frekvenciájú (1-5 Hz) lengések kötegelt vezetékeknél alakulhatnak ki, ahol az egyik vezetékrôl leváló örvények gerjesztik a szomszédos vezetéket. Ezek a lengések kifáradáshoz vezethetnek.

- A szél okozhat kis amplitúdójú (vezeték átmérôhöz hasonló), nagy frekvenciájú (3-150 Hz) lengéseket. Ezek elsődlegesen kifáradásos sérülésekhez vezetnek.

A lengések okozta károk indokolják a kutatást a lengéseket okozó jelenségek megértése, valamint a keletkezô lengések csillapítása céljából. A vezetékról lehulló jég folyamatának és a létrejövő lengéseknek a modellezésére már több mint 50 évvel ezelőtt végeztek kísérleteket, ahol a jeget vezetékre rögzített súlyokkal vették figyelembe [3]. Késóbb a jég okozta terhet több helyen rögzített tesztvezetékkel, a jég lehullását pedig a rögzítések eltörésével is modellezték [4]. Jég lehullását a vezetékról laboratóriumi körülmények között többen is vizsgálták távvezeték kicsinyített modelljén [5, 6], beleértve azt az esetet, amikor az összes jég egyszerre hull le a vezetékról [7], illetve amikor a jég lehullásának folyamata végighalad a vezeték mentén [8].

(C) ELTE, Informatikai Kar, Savaria Múszaki Intézet, 2021

*Kapcsolattartó: Lajber Kristóf, lk@inf.elte.hu

https://doi.org/10.37775/EIS.2021.1.7 
A jelen munka távlati célja az, hogy vizsgálni lehessen a távvezetékekrôl leszakadó jég hatására létrejövő lengéseket és azoknak az esetleges csillapítási lehetőségeit. A mostani fejlesztésnek a fő célja egy tesztberendezés létrehozása, különös tekintettel a vezérlőrendszerre.

\section{A kísérleti modell és a vezérlörendszer}

A vizsgálathoz a távvezeték két fesztávból álló kicsinyített modellje készült el a Savaria Múszaki Intézetben. A jégterhelés modellezésére szakaszonként 8 darab elektromágnessel rögzített súly szolgál. Ezeknek a súlyoknak az időzített elengedésével a vezetékról leszakadó jég jelenségét lehet modellezni. A jegesedett vezetéket érô erôk nagysága határozza meg azt, hogy további jégdarabok leszakadnak-e. Ezt a súlyokat tartó erô változtatásával lehet modellezni ebben a rendszerben. A vezetékekben ébredô erôk mérésére a vezetékek egyik végén háromtengelyes mérôcellákat építettünk be a rögzítési pontoknál.

\subsection{Egyedi vezérlốrendszerrel szemben támasztott követelmények}

A súlyok elengedésének időzítését ms pontossággal kell megvalósítani, hogy a leszakadás folyamata lehetô legjobban közelíthetô legyen. A jelenség modellezése szempontjából fontos, hogy az elengedés sorrendje, ideje és a szorító erô programozható legyen. Illetve az is követelmény, hogy ezek a paraméterek a vezérlőn futó program módosítása nélkül is beállíthatók legyenek. A rendszerrel szemben támasztott követelmények alapján egy mikrovezérlő alapú megoldást találtunk megfelelőnek az elektromágnesek vezérlésére.

\subsection{A kísérleti modell és terhelések}

A távvezeték modellezésére a laboratórium mennyezetére rögzítettük három tartókonzollal, egymástól 8,4 m távolságra, az 1. ábrán látható módon kerültek rögzítésre. A konzolok közé lett kifeszítve a 2. ábrán látható módon a drótkötél, ami a vezetéket modellezi.

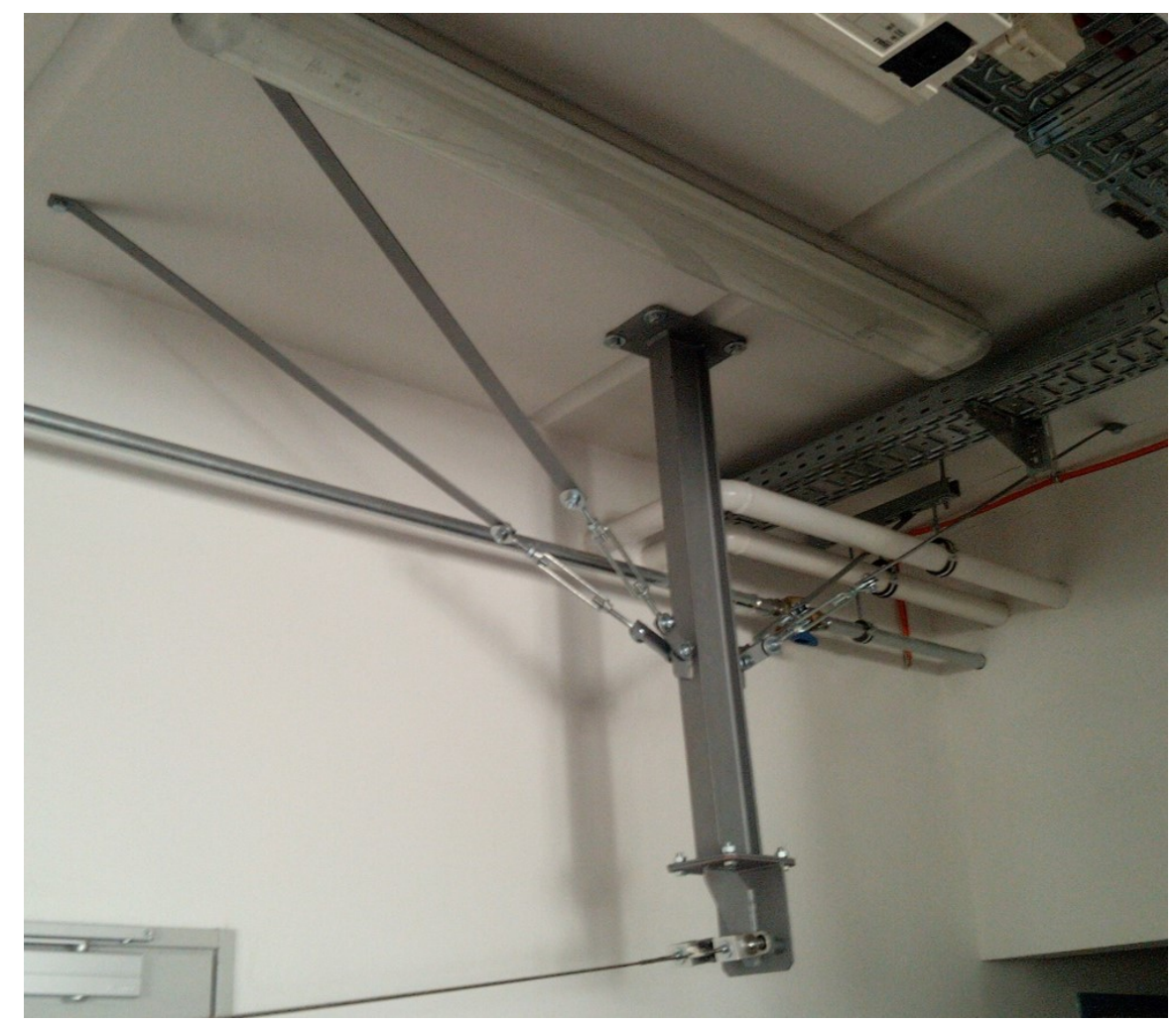

1. ábra: A vezetékek rögzítése 


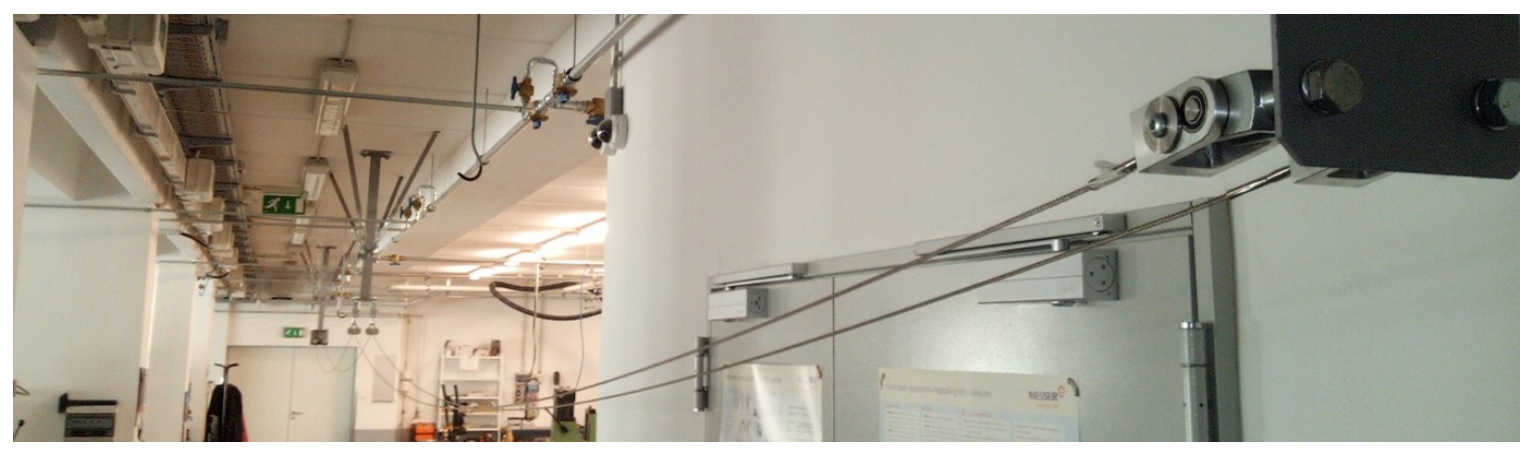

2. ábra: A vezetékmodell

A súlyok csipesz-szerû mechanikával, elektromágnesek segítségével rögzíthetók a vezetékhez. Az elkészült megoldás a 3. ábrán látható. A feladathoz ITS-MS-2520-12VDC típusú elektromágneseket választottunk ki. A mágnesek tekercsei $12 \mathrm{~V}$, névleges egyenfeszültségúek, és $4 \mathrm{~W}$ elektromos teljesítményüek, a névleges húzóerejük $60 \mathrm{~N}$.

\subsection{A vezérlőegység és program}

A követelmények szerint 16 db PWM (Pulse Width Modulation - impulzusszélesség-moduláció [9]) kimenetre van szükség a megfogási erô vezérlésére, USB (Universal Serial Bus - szabványos soros adatátviteli módszer [9]) csatlakozásra és időzítő funkciókra. A Texas Instruments TM4C123GH6P fejlesztôi panelja megfelelô megoldás volt a rendelkezésre álló, 16 csatornás dedikált PWM modullal, aminek minden csatornáját kivezették a fejlesztői panelen is. A vezérlő rendelkezik továbbá $27 \mathrm{db}$ egyenként 32 bit-es idôzítô modullal [10], amelyekkel további szoftveres PWM-csatornák hozhatóak létre. A fejlesztôi panelen az USB kapcsolat gyárilag megvalósított, mivel a programozás és kommunikáció is ezen keresztül történik. A vezérlő $80 \mathrm{MHz}$-es órajele és egyszeres pontosságú lebegópontos számító egysége megfelelő a feladathoz.

A vezérlôprogramot Visual Studio Code - PlatformIO IDE (Integrated Development Environment - integrált fejlesztőkörnyezet [9]) bôvítményével készítettük, Energia keretrendszerben, C++ nyelven [11]. A vezérlőegységen futó program a hardver inicializálása után soros porton keresztül várja az utasításokat. Ezek az utasítások 8 bit-es karakterek formájában érkezhetnek.

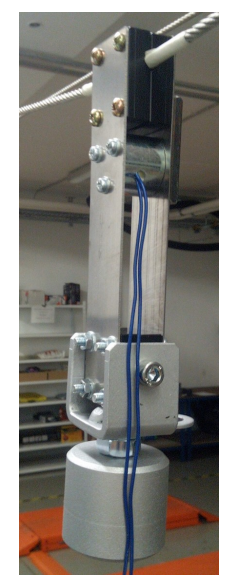

3. ábra: A súlyokat tartó csipesz a vezetéken

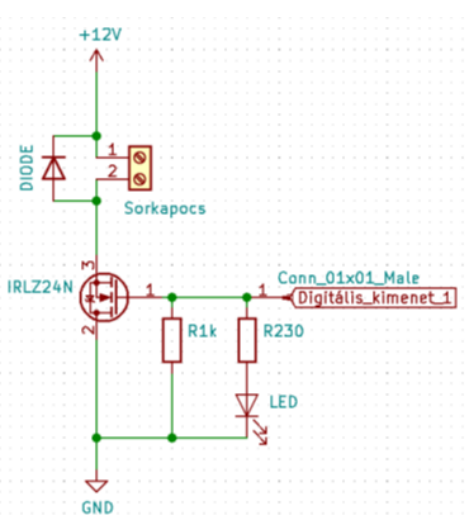

4. ábra: A tervezett MOSFET kimenetek egy csatornájának sematikus rajza 

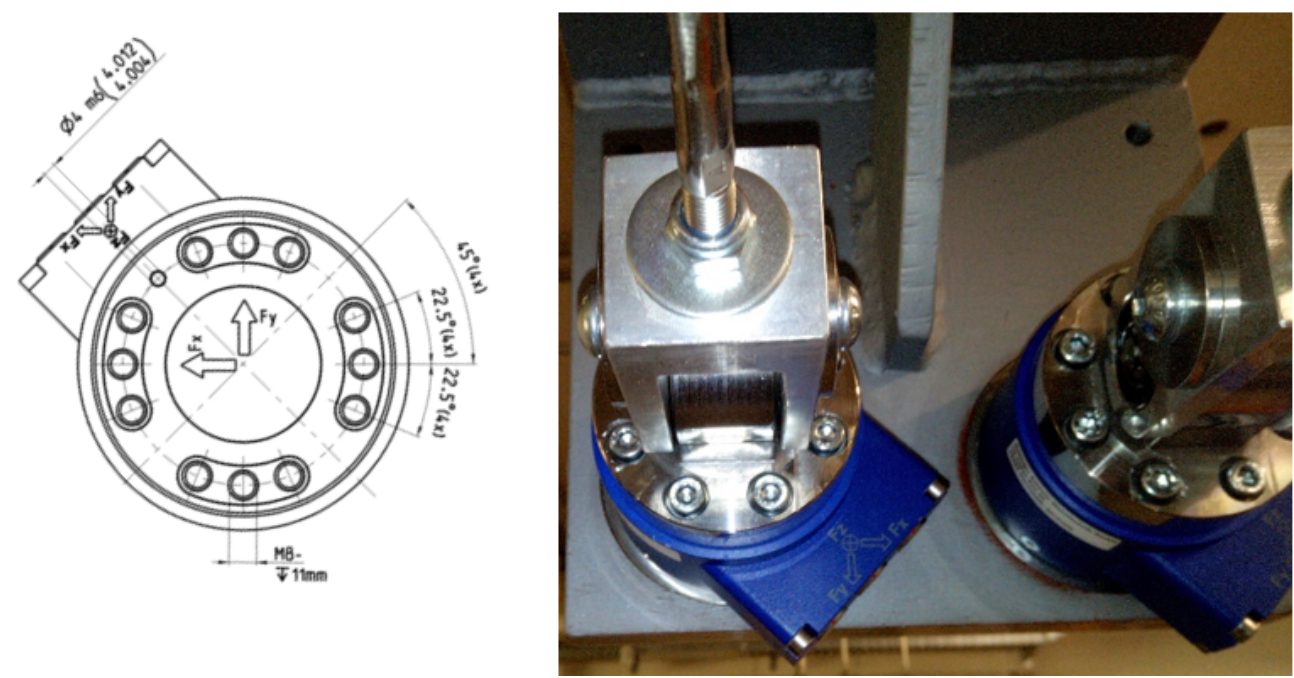

5. ábra: Az erômérô cella múszaki rajza, az erômérési irányokkal és a cellák beépítése [14]

\subsection{Félvezetôalapú szintillesztés}

A feladat kivitelezéséhez félvezető alapú teljesítményillesztést alkalmaztunk, így késóbb a tartóerô állítása is megvalósítható. A MOSFET-es (FET, Field-Effect Transistor - térvezérlésú tranzisztor; MOSFET, Metal-Oxide Semiconductor Field-Effect Transistor -- szigetelt vezérlóelektródás FET [9]) jelszint illesztésnél olyan eszközt kellett választani, amely alkalmas az elektromágnesek $330 \mathrm{~mA}$-es áramának kapcsolására. Mivel az elektromágnesek erősen induktív terhelések, így a kapcsolásukkor keletkező tranziens feszültségcsúcsoktól a rendszert meg kellett védeni.

A MOSFET-ek közül az IRLZ-24N típusút választottuk. Ennek a FET-nek a 18 A-es maximális névleges terhelhetôsége és logikai jelszinttel való kapcsolhatósága előnyös volt a konstrukció szempontjából, mivel a FET-ek névleges terhelése és szükséges kapcsolási ideje nem teszi szükségessé a FET meghajtó modulok alkalmazását [12]. Az eszközök múködési tartományának megfelelően megvalósított kapcsolást az 4. ábra mutatja be. A tranziens hatások ellen a gyakorlatban sokszor alkalmazott 1N4007 típusú diódákat építettünk be az elektromágnesekkel párhuzamosan záró irányba, ezt a 4. ábrán a DIODE felirat jelezi.

\subsection{Adatgyưjtô- és mérôberendezések}

Az adatgyưjtôvel szemben támasztott követelmény az volt, hogy az erômérő cellák jelét megfelelően tudja olvasni és rendelkezzen legalább 6 csatornával, amelyeken szimultán képes méréseket végezni. Ezért egy HBM QuantumX MX840B típusú adatgyújtőt használtunk. Az adatgyưjtő 8 csatornája lehetôvé teszi a két megvalósított vezetéken ébredő erôk 3-3 tengely menti, szimultán rögzítését. A fennmaradó csatornák egyike használható úgynevezett trigger jel (olyan jel, amellyel az adatgyújtés automatikusan elindítható) fogadására. Az eszköz előnye, hogy képes kezelni a jeladókba szerelt TEDS (Transducer Electronic Data Sheet - Jeladó elektromos adatlap) chipeket, így a konfigurációs idố drasztikusan csökken [13]. Az adatgyújtốvel mért adatokat HBM CatmanEasy AP program segítségével rögzítettük.

A vezetékben ébredő erôk méréséhez HBM MCS10-005-3C-FX-FY-FZ-00-00-00 típusú erômérôcellákat alkalmaztunk. Az 5. ábrán jól látható az erômérô cella és mérési irányai. A beépített formában az $y$-tengely függőleges, a z-irány a húzás- és az $x$-irány az oldalirányú erók mérésére szolgál. Az erốmérố mû́szer $x$ és $y$-irányban $1 \mathrm{kN}, z$-irányban $5 \mathrm{kN}$ méréshatárú. 
1. táblázat: Vezérlôutasítások

\begin{tabular}{c|c|c} 
Karakter & Funkció & Paraméter \\
\hline$p$ & kimenet száma & 0-15 közötti \\
\hline$a$ & kimenet aktiválása & 0-ki, 1-be \\
\hline$t$ & $\begin{array}{c}\text { kiválasztott mágnes } \\
\text { kikapcsolásának késleltetése }\end{array}$ & késleltetés ms-ban \\
\hline$r$ & mérés & $\begin{array}{c}\text { 1-mérés indul, } \\
\text { 0-késleltetés törlése }\end{array}$
\end{tabular}

\subsection{A vezérlôprogram kezelése}

A vezérlővel történô, soros port alapú kommunikációhoz a PC (Personal Computer - személyi számítógép) oldalon valamilyen segédprogramra van szükség. A javasolt program a PuTTY nevü alkalmazás. Ezzel az alkalmazással könnyen lehet küldeni a szükséges vezérlókaraktereket. Az elküldött karakterek nyomon követésére a programban érdemes bekapcsolni a local echo (helyi visszhang) funkciót, így a konzolon az elküldött üzenetek is megjelennek. Az üzenetek két részból állnak: egy karakter, amely a kívánt beállítandó funkciót választja ki, amit egy érték követ, amely az előbb kiválasztott funkcióhoz tartozó érték. A rendszer az 1. táblázatban felsorolt utasításokat ismeri fel a jelzett paraméterekkel.

A beállított késleltetési idők nulla idôpontja a mérés kezdete, így az azonos késleltetési idő megadásával az adott mágnesek egyszerre fognak elengedni. A vezérlő minden esetben idő szerint sorba fogja rakni a kimenetek kikapcsolását, így a késleltetési idók megadásának sorrendje nem számít.

\section{Eredmények}

A projekt során megvalósított rendszer használhatóságát a tesztmérések eredményein keresztül mutatjuk be. A méréseket egy vezetékszakaszon, 8 darab súllyal, két különböző idôzítési sémát használva végeztük el. Minden mérésnél 8 darab, 800 g tömegú terhet használtunk. A mérés előtt a csatlakoztatott vezetékkel az erômérô cellák által mért értéket nulláztuk, így csak a terhelések által okozott erôket mértük. A terheket az elsố esetben (6. ábra) egyszerre, míg a második esetben (7. ábra) $100 \mathrm{~ms}$ késleltetéssel engedtük el. A méréseket $300 \mathrm{~Hz}$-es mintavételi frekvenciával rögzítettük, és Matlab segítségével dolgoztuk fel Az erők meghatározása a terhek leejtését megelőző statikus egyensúlyi helyzetben az elsô 300 rögzített adat átlaga alapján történt. Az így kapott eredmények a 2. táblázatban láthatóak.

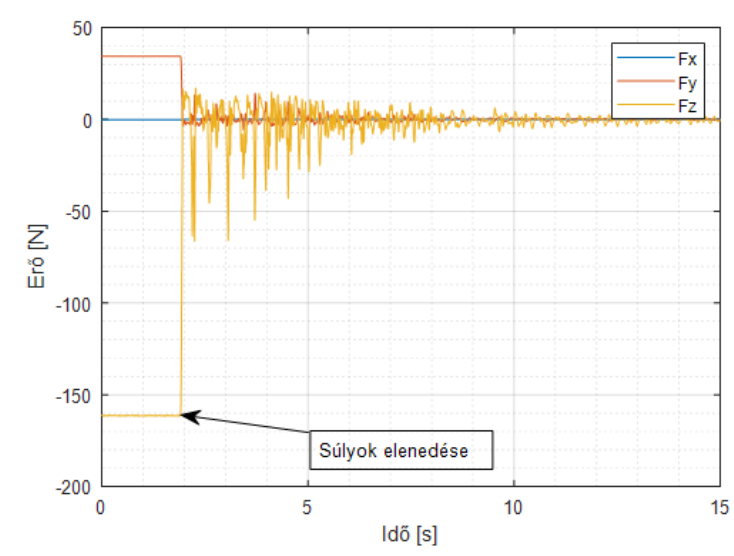

6. ábra: Elsố mérés - terhek lehullajtása egy idôben

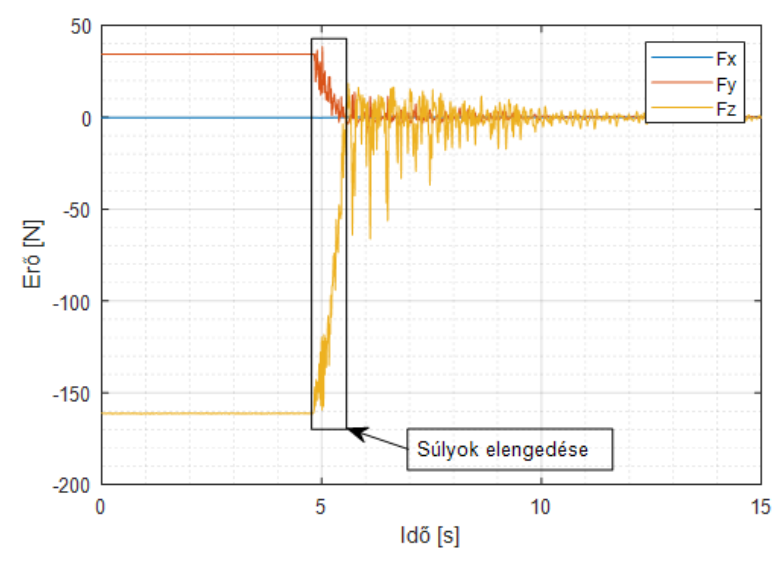

7. ábra: Második mérés - terhek lehullajtása 100 ms idôközönként 
2. táblázat: Kiindulási erốk az egyes méréseknél

\begin{tabular}{c|c|c} 
& 1. mérés & 2. mérés \\
\hline$F_{x}[\mathrm{~N}]$ & -0.2542 & -0.2548 \\
\hline$F_{y}[\mathrm{~N}]$ & 34,4460 & 34,4387 \\
\hline$F_{z}[\mathrm{~N}]$ & $-161,3028$ & $-161,2719$
\end{tabular}

A 6. és 7. ábrákat összehasonlítva jól látható, hogy ha az összes teher egyszerre hull le, akkor az erô z-irányú komponense nagyon gyorsan lecsökken (69 ms) és szinte rögtön kialakul a statikus érték körüli rezgés. Ha viszont a terhek lehullása 100 ms-onként történik, akkor az összes teher lehullása 0,7 s-ig tart (ábrán kerettel jelölve), így a statikus érték körüli lengés is csak ezután alakul ki. Ebben az esetben $10 \mathrm{~s}$ alatt -19,39 dB-el csökkent a lengések intenzitása. A fent rögzített eredmények összhangban vannak a mérések során tapasztaltakkal.

\section{Irodalomjegyzék}

[1] EPRI, Transmission Line Reference Book: Wind-Induced Conductor Motion, Electric Power Research Institute, Palo Alto, CA, USA, 1979.

[2] M. Farzaneh, Atmospheric Icing of Power Networks, Springer Science+Business Media B.V., 2008, ISBN: 978-1-4020-8530-7, CrossRef

[3] V.T. Morgan, D.A. Swift, Jump height of overhead-line conductors after the sudden release of ice loads, Proceedings of the Institution of Electrical Engineers 111(10), 1964, pp. 1736-1746, CrossRef

[4] P. Van Dyke, A. Laneville,, Simulated ice shedding on a full-scale test line, Proc. 8th Int. Symp. Cable Dynam., Paris, France, 2009.

[5] A. Jamaleddine, G. McClure, J. Rousselet, R. Beauchemin, Simulation of ice shedding on electrical transmission lines using ADINA, Computers \& Structures 47(4-5), 1993, pp. 523-536, CrossRef

[6] G. Huang, B. Yan, N, Wen, C. Wu, Q. Li, Study on jump height of transmission lines after ice-shedding by reduced scale modeling test, Cold Regions Science and Technology 165, 2019, 102781, CrossRef

[7] L.E. Kollár, M. Farzaneh, Modeling sudden ice shedding from conductor bundles, IEEE Transactions on Power Delivery 28(2), 2013, pp. 604-611, CrossRef

[8] L.E. Kollár, M. Farzaneh, P. Van Dyke, Modeling Ice Shedding Propagation on Transmission Lines with or without Interphase Spacers, IEEE Transactions on Power Delivery 28(1), 2013. pp. 261-267, CrossRef

[9] Magyar elektronika, letöltés dátuma: 2021.04.20, url

[10] Tiva ${ }^{T M}$ TM4C123GH6PM Microcontroller DATA SHEET, 2007-2014 Texas Instruments Incorporated

[11] Benedek Z., Levendovszky T., Szoftverfejlesztés $C++$ nyelven, SZAK Kiadó, 2007, ISBN 978963-9131-94-1

[12] A. Kay, T. Green, Analog Engineer's Pocket Reference, Texas Instruments Incorporated, 2019. 
[13] QuantumX MX840 Universal Amplifier Data Sheet, Hottinger Brüel \& Kjaer GmbH, letöltés dátuma: 2021.04.20, url

[14] MCS10 sensor datasheet, letöltés dátuma: 2021.04.20, url 